\title{
A múzeumi élmény a 21. században. Bécs, Budapest és Prága versenyképessége a múzeumlátogatói értékelések tükrében
}

\author{
Schultz Éva \\ Budapesti Gazdasági Egyetem
}

\begin{abstract}
A TANULMÁNY CÉLJA
A tanulmány célja Bécs, Budapest és Prága komparatív turisztikai elemzésének új szemponttal való bővítése. A múzeumok a városi turizmus kiemelt vonzerői, a turisztikai márka alkotóelemei, a minőségi turizmus szereplői. Segítik a turizmus fenntarthatóságát a helyi kultúra megismerésének lehetősége és szezonnyújtó kiállításaik révén, bár egyre gyakrabban szembesülnek a túlturistásodás kihívásaival. Az intézménytípus hagyományos örökség- és identitásőrzésben játszott kultúraközvetítő szerepét átértelmező folyamat a 20. század vége óta zajlik. Ennek során az informális élethossziglani tanulás tereként, a globális jól-lét szempontjából fontos intézményként, párbeszédet generáló, a társadalmi egyenlöséget segítő közösségi térként egyaránt definiálták.
\end{abstract}

\begin{abstract}
ALKALMAZOTT MÓDSZERTAN
A turisztikai megközelítés szerint a látogatót az élményígéret vonzza egy múzeumba. A látogatói élmény összetett jelensége napjainkban fontos interdiszciplináris kutatási terület. A tanulmány Budapest és regionális turisztikai versenytársai múzeumainak vonzerejét, valamint az irányukban támasztott látogatói elvárásokat és elégedettséget vizsgálja a TripAdvisor-on megjelenő vélemények tartalomelemzésének módszerével.
\end{abstract}

\section{LEGFONTOSABB EREDMÉNYEK}

A legjobb értékelést szerzett múzeumok többsége egyedül Bécsben klasszikus, nemzetközi vonzásintenzitású kulturális márka. Budapest és Prága esetében jelentős a viszonylag fiatal, magán/alapítványi üzemeltetésü, szolgáltatás-centrikus, különleges témájú intézmények jelenléte. Az előbbi csoportba tartozó múzeumok kapcsán a látogatómenedzsment hiányosságait, az utóbbiak esetében a kiállítás méretét és/vagy színvonalát éri leggyakrabban kritika. A legtöbbször említett fogalomtípus az élmény minősítése, amiben kiemelt szerepet játszik a személyes szolgáltatás és interakció.

\section{GYAKORLATI JAVASLATOK}

A kutatás eredményei segíthetik a múzeumok pozícionálását a turisztikai piacon. A főbb látogatói szegmensek, küldőpiacok igényeinek megismerése további kutatások révén feltétele a múzeum, mint szolgáltató kultúraközvetítő intézmény sikeres müködésének több szempontból is (igényre szabott interpretációs lehetőségek, minőségbiztosítás, látogatómenedzsment, potenciális piacok feltárása és elérése).

Kulcsszavak: városi turizmus, múzeum, látogatói élmény

DOI: 10.15170/MM.2020.54.02.07 


\section{BEVEZETÉS INTRODUCTION}

A múzeumok jelentős szerepet játszanak a városi turizmusban. A városi brand kiemelkedő kulturális elemei, meghatározó alkotórészei egy városrész épített környezetének, atmoszférájának, egyedi élményígéretének, így a városi turizmus kibővített 5A-rendszeréből több tényező kapcsán is említhetök (Gonda - Csapó 2014, Zátori 2014). A 19. századi múzeumalapítási hullám okán gyakran önmagukban is látnivaló történelmi épületekben találhatók, többnyire központi elhelyezkedésük szintén növeli vonzerejüket. A kortárs múzeumalapítások sokszor barnamezős városi területek rehabilitációját, dzsentrifikációját, imázsváltását idézik elö, ami elősegíti azok bekapcsolódását a turizmusba. A múzeumok lehetőséget kínálnak a turizmus időbeli dekoncentrációjára, ezáltal a fenntartható, minőségi turizmustervezés eszközei lehetnek. Egy jól pozícionált időszakos kiállítás az intézmény, a téma és marketingkommunikáció függvényében - nemzetközi attrakcióvá válhat az alacsony látogatószámú időszakokban. A múzeumi hálózatok - térbeli és időszakos együttmüködések - például kulturális klaszterekként vagy a tematikus évek együttmúködései kapcsán ,városi defibrillátorrá” válhatnak (Mantziou 2019). Végül, de nem utolsó sorban fontos kiemelni a múzeumok nemzeti és helyi identitásban, kollektív emlékezetben, informális oktatásban játszott szerepét, vitathatatlan társadalmi értékét, ami a lokális közösség által támogatva válhat egyedi vonzerővé.

A tanulmány célja a múzeumok szerepének vizsgálata TripAdvisor-vélemények alapján Bécs, Budapest és Prága vonatkozásában. A kutatási eredmények várhatóan új szemponttal gazdagítják a három főváros komparatív turisztikai elemzését.

\section{BÉCS, BUDAPEST ÉS PRÁGA TURIZMUSA \\ TOURISM IN VIENNA, BUDAPEST AND PRAGUE}

A sok szempontból közös földrajzi-regionális jellemzők mellett a három város mérete is hasonló. A lakosságszámra és az alapterületre vonatkozó adatok 2018-ban a következök voltak: Bécs esetében 1888776 fö és $414 \mathrm{~km}^{2}$, Budapest esetében 1749734 fö és $525 \mathrm{~km}^{2}$-, Prága esetében 1308 632 fö és $298 \mathrm{~km}^{2}$ (www.wien.gv.at, www.ksh.hu, CZSO 2020b). A számos korszakban összefonódott történelem ellenére az osztrák, a magyar és a cseh fóváros turisztikai kínálata (vonzerő és attrakciók, turisztikai infra- és szuprastruktúra), annak marketingje (főleg az imázs, a márka és az arculat tekintetében) és ár-érték aránya eléggé különböző, ami a kereslet eltéréseiben is megmutatkozik. 2018-ban a nemzetközi turistaérkezés alapján a világ városainak rangsorában Prága a 22., Bécs a 37. és Budapest a 62 . helyen állt. Mivel ez a mutató nem veszi figyelembe a tranzitlátogatókat, így a három főváros tényleges külföldi turistáinak számát mutatja. Prága az európai top 10-ben a 6., Bécs a 10 helyen áll (Euromonitor International 2019). Ahogy az 1. táblázat mutatja, az összes turistaérkezést tekintve is Prága vezet, Bécs a második és Budapest a harmadik. A növekedés üteme a teljes vendégszám tekintetében is Bécs esetében volt a legmagasabb 2018-ban az előző évhez képest, akárcsak vendégéjszakák száma. A három fővárosban hasonlóan rövid tartózkodási idő tipikus a jellemzően (hosszú) hétvégi városlátogatások kapcsán, amit Európában erösít a viszonylagosan kis távolság és a diszkont légitársaságok felvirágzása miatt (UNWTO 2019). A vendégszám- és vendégéjszaka-beli különbséget eredményezheti a közlekedési infrastuktúrában, a kínálat vonzásintenzitásában rejlő eltérés (akár az attrakciókat, akár az infra- és szuprastrukturális elemeket tekintve), egy speciális keresleti szegmens megjelenése és a marketingmunka hatékonysága (vagy akár mindezek együttesen). 


\section{1. táblázat: Bécs, Budapest és Prága 2018. évi turizmusának összehasonlítása turisztikai mutatók alapján (bázisév: 2017) \\ Table 1. Touristic comparison of Vienna, Budapest and Prague based on statistical data (base-year: 2017)}

\begin{tabular}{|l|l|l|l|}
\hline Főbb turisztikai mutatók & Bécs & Budapest & Prága \\
\hline Nemzetközi érkezés (fö) & $\begin{array}{l}7539810 \\
(+6,2 \%)\end{array}$ & $\begin{array}{l}4499829 \\
(+5,3 \%)\end{array}$ & $\begin{array}{l}7895002 \\
(+3,2 \%)\end{array}$ \\
\hline $\begin{array}{l}\text { Vendégéjszaka a turisztikai szálláshelyeken } \\
\text { (darab) }\end{array}$ & $\begin{array}{l}16483497 \\
(+6,3 \%)\end{array}$ & $\begin{array}{l}10370479 \\
(+3 \%)\end{array}$ & $\begin{array}{l}18256481 \\
(+1,1 \%)\end{array}$ \\
\hline Átlagos tartózkodási idő (nap) & $2,1(-0,1 \%)$ & 2,3 & $2,3(-0,1 \%)$ \\
\hline Szállodák (és panziók) száma (darab) & $426(-2,3 \%)$ & $336(+1,8 \%)$ & $531(+0,9 \%)$ \\
\hline $\begin{array}{l}\text { Szállodák (és panziók) kapacitása (szobák } \\
\text { száma) }\end{array}$ & $34107(+1,5 \%)$ & $20268(+2,6 \%)$ & $\begin{array}{l}35508 \\
(+1,3 \%)\end{array}$ \\
\hline $\begin{array}{l}\text { Szállodák (és panziók) kapacitása (féróhelyek } \\
\text { száma) }\end{array}$ & $67816(+2,2 \%)$ & $43458(+0,8 \%)$ & $\begin{array}{l}72614 \\
(-1,6 \%)\end{array}$ \\
\hline $\begin{array}{l}\text { Szállodák (és panziók) kapacitás kihasználtsága } \\
\text { (szoba) }\end{array}$ & $60,2 \%(+1,3 \%)$ & $76,6 \%(+1,7 \%)$ & $\begin{array}{l}69,3 \% \\
(-0,2 \%)\end{array}$ \\
\hline REVPAR (EUR) & $79,5(+9,4 \%)$ & $68,3(+4,7 \%)$ & $71,2(1,7 \%)$ \\
\hline $\begin{array}{l}\text { Részesedés az ország nemzetközi turistaérke- } \\
\text { zéseiből }\end{array}$ & $24,5 \%(+0,4 \%)$ & $26,2 \%(-1 \%)$ & $\begin{array}{l}37,3 \% \\
(-2,9 \%)\end{array}$ \\
\hline $\begin{array}{l}\text { Részesedés az ország belföldi vendégérkezé- } \\
\text { seiből }\end{array}$ & $11,7 \%(+0,7 \%)$ & $9,8 \%(+9,3 \%)$ & $11,5 \%(+0,5)$ \\
\hline $\begin{array}{l}\text { Részesedés az ország összes vendégéjszaka } \\
\text { számából a turisztikai szálláshelyeken }\end{array}$ & $11 \%(+0,3 \%)$ & $33,4 \%(-0,5 \%)$ & $32 \%(-2 \%)$ \\
\hline
\end{tabular}

Megjegyzés: mivel az elözetes adatok nem állnak mindhárom város esetében rendelkezésre, ezért az utolsó teljes statisztikai év mutatóit vizsgálom. A turisztikai szálláshelyek jogi besorolása és az azokra vonatkozó adatközlés országonként eltérö. Az osztrák statisztikákban a szállodák és a panziók közösen szerepelnek, a cseh statisztika a „közösségi szálláshely” kategórián belül a 4 csillag alatti szállodák adatait együtt mutatja kategóriánként a motelek, botelek és a garnihotelek adataival, ami a budapesti adatokhoz képest a nagyságrendi eltérést eredményez. A hazai adatok csak a szállodákra vonatkoznak. A különbségekre utalok a szálláshely egységek számától kezdödö sorok megnevezésében.

Forrás: Statistik Austria (2020), KSH (2019), MSZÉSZ (2019), MTÜ (2019a, 2019b, 2019c), www.praguecitytourism.cz, Prague City Tourism (2019), CZSO (2020a) (saját szerkesztés)

Bécsben és Prágában - részben a városok közötti méretkülönbségből fakadóan - ugyan kisebbek a részben világörökségi védelem alatt álló városközponti területek, vagyis a turisztikai magterületek, mint Budapesten, de nagyobb arányban felújítottak. Bécs és Prága markáns imázselemekkel felépített, bejáratott turisztikai brand. A Bécs-márka elemei főként a „császárváros”, a klasszikus zene és az operett, a Sisi-kultusz, a szecessziós múvészet és világhírü múzeumok, a karácsonyi vásárok, a kávéházi gasztronómia stb., ahol a hagyományos városi turizmus mellett erős a hivatásturizmus jelenléte.
Prága egy ideig szintén császárváros volt, de inkább a régióban egyedülálló gazdagsággal megmaradt, részben mitikus középkori városmagja és Zsidónegyede, sörkultúrája, a világhírü cseh irodalom és filmmüvészet révén ismert. Budapestről mindez egyedülálló látképe és gyógyfürdői, világhírủ zeneszerzői, különleges városszövete és nemzetközileg egyre elismertebb kulináriája ellenére sem mondható el, inkább egy alulról - jelentős mértékben az online turisztikai portálok véleményein - épülö, „felfedezett” és még mindig nem igazán körülhatárolt márkaként jelentkezik. A bulinegyed-föváros 
szerep már jelenleg sem fenntartható, stratégiai célként minőségi átalakulás nélkül egyáltalán nem fogalmazható meg. A mennyiségileg igen látványosan növekvő budapesti turizmusnak az eredménye a szállodaépítési „boom” is, ami a magyar fővárosban jelenleg - a három főváros közül egyedüliként - tapasztalható (turizmus.com 2020). A kiadható szállodai (és panzió) szobák száma viszont folyamatosan nő Bécsben és Prágában is, ennek hátterében a szállodai szobaátalakítások éppúgy állhatnak, mint a növekvő kereslet igényeit kielégítő nemzetközi szállodacsoportok magas szobaszámú beruházásai (www.wien.gv.at, www.praguecitytourism. $\mathrm{cz})$.

A REVPAR-mutató értéke Bécsben a legmagasabb (az egész régiót tekintve), a budapesti értéke egyre inkább közelíti a prágait. A szállodai kapacitás kihasználtsági rátája a cseh fővárosban az 5 csillagos, az osztrák és a magyar fơvárosban az egy kategóriával alacsonyabb szálláshelyeken a legmagasabb, ami részben a vendégkör ( $\mathrm{pl}$. az orosz) luxus iránti igényével, részben a szálláshelytől is elvárt egyre magasabb élményfaktorral, részben a hivatásturizmussal magyarázható (www. wien.gv.at, Prague City Tourism 2019).

Bécs részesedése a legkisebb az ország nemzetközi érkezéseiből, Prágáé a legmagasabb. Ennek oka részben Ausztria Csehországét kétszeresen meghaladó nemzetközi vendégérkezés számával (29 460000 , illetve 13665000 2017-ben), részben az osztrák természeti vonzerőkkel indokolható (UNWTO 2019). Ausztria a „legalpesibb” ország, területének kétharmadát borítják magas hegyvonulatok, ami jelentős szerephez juttatta a nemzetközi síturizmusban. Az osztrák történelem és az állam tartományi felépítése vezetett a helyi identitás örökségturizmusban való fokozott megjelenéséhez. Ezt a területi dekoncentrációt sem Csehország, sem Magyarország - dacára gazdag gyógy- és termálvíz készletének - nem tudja produkálni. A belföldi vendégforgalom szempontjából nem meghatározó szerepű egyik főváros sem, ami az országok kis méretével, a fővárosok könnyü elérhetőségével, emellett Csehországban és Magyarországon az országos átlaghoz képest magasabb szállásdíjárakkal is magyarázható az eltérő motivációs igények mellett (inkább a belföldi kirándulóturizmus van jelen, MSZÉSZ 2019). Az országos vendégéjszaka számból való részesedés Budapesten és Prágában a legmagasabb, ezekben a városokban összpontosul a turizmus a legnagyobb mértékben. Ennek irányítása Magyarország mellett Csehország hosszú távú célja is kell, hogy legyen a túlturistásodás negatív hatásainak elkerülése végett (UNWTO 2019, Csapó 2020).

\section{A KUTATÁS MÓDSZERTANA METHODOLOGY}

A kutatás módszere az önkényes mintavételủ online tartalom- és szövegelemzés volt 2020 januárjában. A mintavétel a TripAdvisor legjobb értékelések alapján felállított múzeumi rangsora volt Bécs, Budapest és Prága vonatkozásában. Mindhárom fóváros top 10 múzeuma esetében intézményenként 10, összesen 300 angol nyelvú, legalább öt soros, nem pusztán leíró értékelés tartalmát elemeztem elöre meghatározott szempontrendszer alapján. A vélemények kiválasztásakor fontos szempont volt az időbeli szórás és a lehetőségekhez mérten széles skálájú értékelés.

\section{KUTATÁSI EREDMÉNYEK RESEARCH FINDINGS}

Az adatbázis tisztítása (műkereskedelmi galériák és duplumok eltávolítása) után Bécsben 121, Budapesten 138, Prágában 131 múzeumról található értékelés a TripAdvisor-on. Fontos leszögezni, hogy az online felhasználók nem csak a jogi értelemben vett, bejegyzett múzeumokat, hanem az ilyen név alatt müködő intézményeket, vagy pusztán az általuk múzeumként definiált attrakciókat is itt véleményezik. A vizsgálatból csak az utóbbiakat zártam ki, mivel az előbbiek jellemzően piaci rést betöltő, sokszor a helyi kulturális örökséget élményszerüen bemutató, saját gyűjteménnyel bíró, többnyire magán üzemeltetésủ kiállítóhelyek, így megfelelnek korunk látogató igényeinek (a múzeumi alapfunkciók közül rendelkeznek a megörzéssel és a bemutatással). Ennek következtében mindhárom föváros esetében megjelennek a top 10-ben. 101 bécsi, 78 budapesti és 93 prágai múzeumot értékeltek látogatóik pontszámmal, ami az osztrák és a magyar főváros esetében azonos, a cseh főváros esetében ettől kissé elmaradó átlagértéket eredményezett (4,1, illetve 3,8 az ötös skálán). 


\section{2. táblázat: Bécs, Budapest és Prága legjobb értékelést szerzett múzeumai a TripAdvisor-on}

Table 2. The best reviewed museums of Vienna, Budapest and Prague on TripAdvisor

\begin{tabular}{|l|l|l|}
\hline Bécs & Budapest & Prága \\
\hline Hofburg & Flippermúzeum & Nemzeti Filmmúzeum \\
\hline Belvedere & Csokoládé Múzeum & $\begin{array}{l}\text { A Heydrich-féle Terror Nemzeti } \\
\text { Hőseinek Emlékhelye }\end{array}$ \\
\hline „A Harmadik Ember” Múzeum & $\begin{array}{l}\text { Zwack Múzeum és Látogató- } \\
\text { központ }\end{array}$ & Cseh Gránát Múzeum \\
\hline Kunsthistorisches Museum & $\begin{array}{l}\text { Sziklakórház és Atombunker } \\
\text { Múzeum }\end{array}$ & Lobkovitz-palota \\
\hline 3D PicArt Museum & Holokauszt Emlékközpont & Kbely Repüléstörténeti Múzeum \\
\hline Naturhistorisches Museum & Magyar Nemzeti Galéria & Nemzeti Technikai Múzeum \\
\hline Albertina & Szépmúvészeti Múzeum & Speculum Alchimiae Museum \\
\hline Leopold Museum & Houdini Ház & Érzékszervek Múzeuma \\
\hline Császári Kincstár & Magyar Nemzeti Múzeum & Cseh Zenetörténeti Múzeum \\
\hline MuseumsQuartier Wien & Victor Vasarely Múzeum & $\begin{array}{l}\text { Szent Ágnes Konvent Múzeuma } \\
\text { (a Cseh Nemzeti Galéria közép- } \\
\text { kori gyújteménye) }\end{array}$ \\
\hline
\end{tabular}

Megjegyzés: a külföldi múzeumok nevei abban az esetben olvashatók eredeti nyelven, ha nemzetközi márkanévrôl van szó, vagy ha a forditás nem segiti a múzeumi tematika megértését. A sötétszürke mezőben feltüntetett múzeumok magán, illetve alapitványi fenntartású intézmények. A középszürke hátterü múzeumok esetében a TripAdvisor kiemelt vendégelégedettségi fórumként jelenik meg (a véleményekre adott válaszok alapján). Világosszürke mezöben olvasható azoknak a múzeumoknak a neve, amelyekre mindkét elöbbi állitás igaz.

Forrás: saját szerkesztés

A 2. táblázat mutatja az értékelések alapján a 10 legkedveltebb múzeumot A bécsi múzeumokról írták magasan a legtöbb véleményt (59 942, Budapest: 12 120, Prága: 8 263), az átlagos elégedettség Bécs és Prága estében magasabb (4,6 illetve 4,7, míg Budapest esetében 4,4). A harminc intézmény 90\%-a elnyerte a TripAdvisor legmagasabb elismerését, a Kiválósági Tanúsítványt.(kivéve a Magyar Nemzeti Múzeumot, a Vasarely Múzeumot és a 3DPicArt-ot). A vizsgált múzeumok Bécsben a TripAdvisor által ajánlott 831 program között a 3-27. helyen, Budapesten 600 között a 9-84. helyen, Prágában 1104 között a 6-48. helyen állnak.

A tartalomelemzés szempontrendszerének szakirodalmi háttereként a budapesti múzeumok és az új muzeológia összefüggéseire, a múzeumi élményre és a múzeumi látogatótipológia rendszerére vonatkozó vizsgálatok szolgáltak. A budapesti múzeumok vonzerejében a történelmi épület, a központi elhelyezkedés, a tematika, és az interaktivitás kiemelkedő szerepet játszik (Bodnár és tsai 2017). A múzeumi látogatói élmény Pine és Gilmore elméletén alapuló rendszere a passzív befogadót a szórakozás és az esztétika, az aktív résztvevőt a tanulás és a bevonódás alapján bontja szegmensekre. A szórakozni és a tanulni vágyó látogató felszívja a múzeumban megtapasztaltakat, míg az esztétikumot és az aktív bevonódást kereső elmerül azokban. Az aktív bevonást célzó múzeumi interpretáció eszközei az interaktivitás, az edutainment, a közös alkotás, az infokommunikációs technológiák, az ikonikus autenticitás, valamint a multiszenzorális élmény (Bodnár 2019). A múzeumi látogatók falk-i tipológiája megkülönbözteti a felfedezőket, a másokat kísérőket, az élménykeresőket, a szakmabelieket vagy a hobbi-látogatókat, a feltöltődőket, a kulturális affinitásúakat és a „zarándokokat” (erkölcsi kötelességtudat vagy rajongás által motivált látogatókat, Falk - Dierking 2016). Mindezeket figyelembe véve és a vizsgált szövegek 
sajátosságaira adaptálva, valamint kiegészítve a turisztikai termékek és szolgáltatások néhány jellemző aspektusával, egy 10 szempont és 33 alszempont alapján összeállított rendszer szerint elemeztem az értékelések tartalmát. A szempontok többsége (8) a kínálattal kapcsolatos. Mivel a kutatás alapját a legjobb értékeléseket szerzett múzeumok képezték, így a vélemények várhatóan pozitív tartalmának kvalitatív szempontú elemzése mellett a kvantitív vizsgálat is indokolt volt arra irányulóan, hogy a látogatók mit említenek a legygyakrabban. Az 1. ábráról leolvasható, hogy összesítve a vonzerő, a gyüjtemény és az interpretáció áll a látogatói vélemények fókuszában. A szempontok alaposabb megértését az alszempontok rendszere segíti (2. és 3. ábra).

\section{1. ábra: A TripAdvisor értékelések szövegelemeinek mennyisége az elemzési szempontrendszer viszonylatában}

Figure 1. Number of TripAdvisor reviews' text elements in relation to the analysis criteria

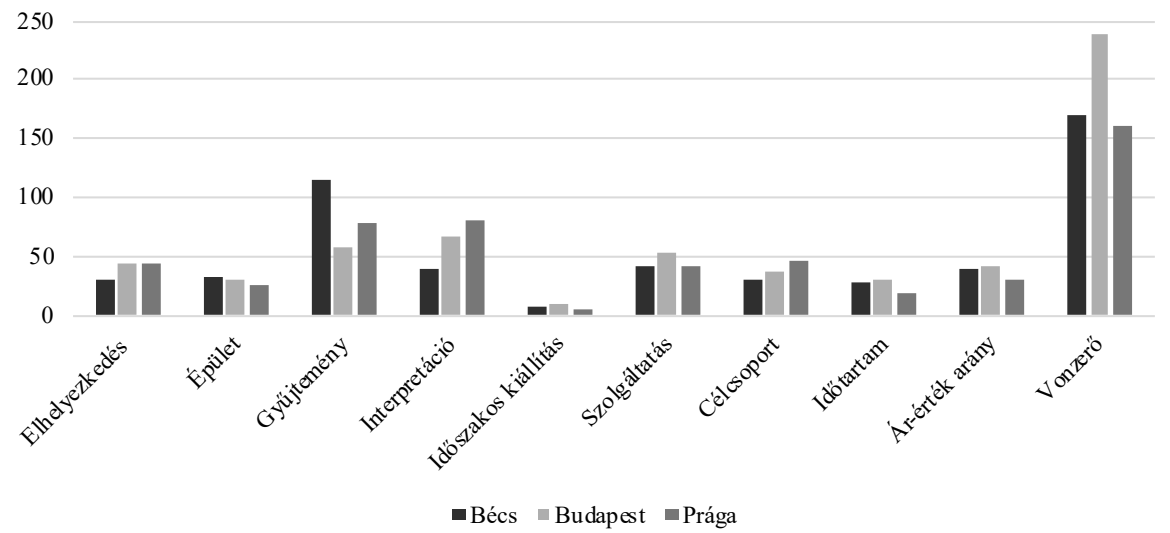

Forrás: saját szerkesztés

2. ábra: A TripAdvisor értékelések szövegelemeinek mennyisége az elemzési alszempont-rendszer viszonylatában 1.

Figure 2. Number of TripAdvisor reviews' text elements in relation to the analysis sub-criteria 1

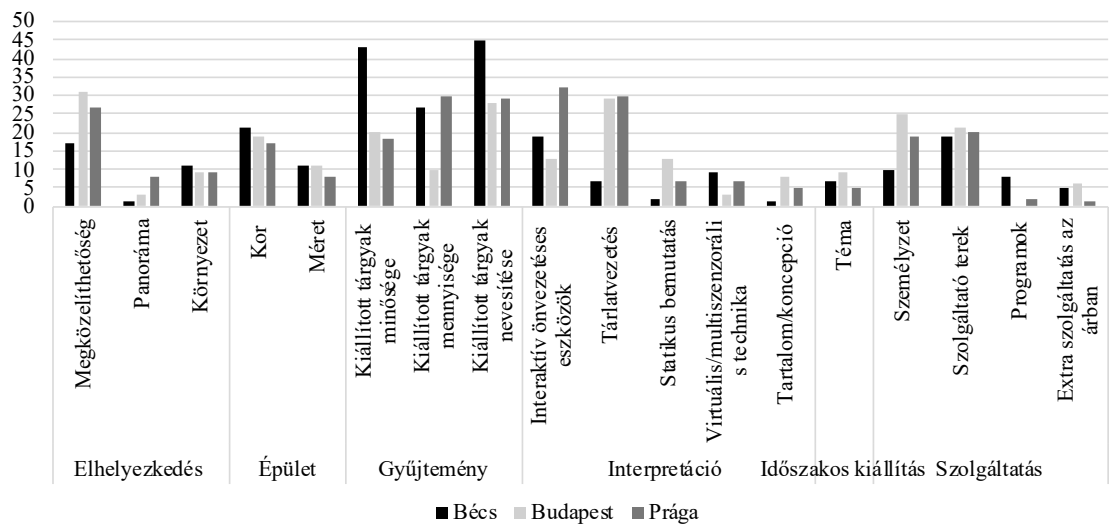

Forrás: saját szerkesztés 


\section{3. ábra: A TripAdvisor értékelések szövegelemeinek mennyisége \\ az elemzési alszempont-rendszer viszonylatában 2.}

\section{Figure 3. Number of TripAdvisor reviews' text elements in relation to the analysis sub-criteria 2}

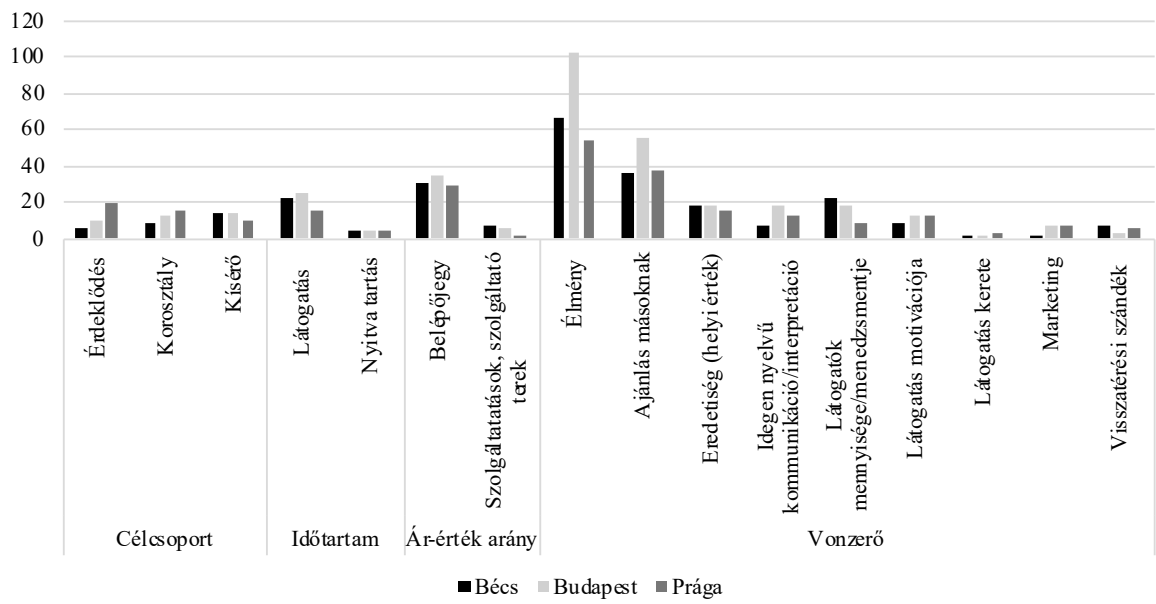

Forrás: saját szerkesztés

Meglepö, hogy a központi elhelyezkedés a témaspecifikus múzeumok esetében egyáltalán nem meghatározó (Bécsben 1, Budapesten 5, Prágában 4 múzeum). A TripAdvisor véleményezői jellemzően segítik a többi látogatót az útvonal és az utazási időtartam leírásával, ami nem csökkenti a látogatás motivációját és az értékelés pontszámát. Többen említik a múzeum környezete által kínált lehetöségeket is (park, gasztronómia, múzeumi negyed). A múzeumi épületek közül a történelemben egykor különleges szerepet játszó, önmagukban is vonzerőt jelentő műemlékek (kastélyok, egyházi épületek, földalatti létesítmények) jelennek meg a kiállítások értékét növelő tényezőként. Az épületek mérete kapcsán kevésbé a nagyság lenyügöző mivolta, mint a kisebb múzeumok „,rejtett” gyöngyszemként való aposztrofálása jellemző. Ez összefüggésben ál a könnyebb tájékozódás mellett a látogatói tömeg okozta kellemetlenségek elkerülésével, valamint a beavatottság és az utóbbiakban jellemző tárlatvezetés okozta személyesség élményével (ez megmutatkozik az interpretáció, a célcsoport, illetve a vonzerő vizsgálati szempontjainál).

A tematika kapcsán a véleményekben a legnagyobb hatást kiváltó és ezáltal kiemelten, nevesítve szereplő kiállítási tárgyak, akárcsak azok minőségének/mennyiségének (dicsérö) említése érthető módon Bécs gazdag, egykori császári lakosztályai és mủvészeti gyüjteményei kapcsán a legjellem- zőbb, amiket a prágai technikatörténeti múzeumok követnek. A vizsgált múzeum fele (16) képzőmüvészeti és történelmi témájú. Az időszakos kiállitások önmagukban is látogatási/visszatérési motivációt jelenthetnek, bár az elemzett véleményekben a vártnál kisebb mértékben kerültek említésre Budapest és Bécs képzőmüvészeti gyüjteményei kapcsán. Az interpretáció vonatkozásában szintén a vártnál kisebb szerepet kap az értékelésekben a virtuális és a multiszenzorális technika. Az interaktív, önvezetéses eszközök közül is legtöbbször az e téren hagyományosnak számító audioguide-ot említik a látogatók, a digitális megoldások csak témaspecifikusan (főleg Budapest és Prága múzeumaiban) játszanak szerepet. A tárlatvezetés gyakori (pozitív minősítésű) előfordulása alátámasztja a személyes kapcsolat fontosságát az élményszerzésben.

A múzeumok szolgáltató intézmények a Múzeumok Nemzetközi Tanácsa legújabb definíció javaslata és a magyar jogi szabályozás szerint is (ICOM 2019; 1997/CXL. tv.). A látogatói vélemények ebben a kontextusban legtöbbször a személyzetet és a múzeumi kávézót, valamint az ajándékboltot minősítik (az utóbbiakat jellemzően pozitívabban, mint az előbbit), ami aláhúzza a fogadó- és vendégterek szerepét egy kulturális intézményben. A múzeumi programok ritkábban jutnak el a TripAdvisor-t használó turistákhoz, viszont minden, inkább a magánmúzeumok esetében tipikus, 
a látogatáson felüli szolgáltatás (ajándék nyomtatott fénykép, saját filmösszeállítás, kóstoló) mély nyomot hagy bennük.

Az értékelők javaslatai a széles körü tematika okán föleg a prágai múzeumok esetében szólnak a Falk-féle szakmabeli és hobbi-látogatókhoz, a bécsi történelmi és müvészeti gyüjtemények kapcsán meghatározóan a kulturális affinitásúakhoz és mindhárom főváros világháborús-hidegháborús múzeumainak esetében pedig az ún. zarándokokhoz. Az egyéb szempontok szerint nevesített keresleti szegmensek leggyakrabban a családos látogatók a gazdag interpretációs eszköztárú, illetve a generáció-független témájú (természet- és tudománytechnika, érzékelés) kiállításokhoz köthetően.

A látogatás idejével kapcsolatos javaslatok Bécs esetében többször kitérnek az optimális látogatószámú időszakokra, valamint általában a szükséges időtartamra (ez utóbbi meglepően nagy szórást mutat, ami részben a gyüjtemények méretével, részben a motivációk sokféleségével magyarázható). Az ár-érték arányról formált vélemények túlnyomó többsége mindhárom főváros vizsgált múzeumai kapcsán elégedettségről tanúskodik.

A múzeumok vonzerőként való megjelenésének vizsgálata tartalmazza a legtöbb alszempontot. A vélemény legnagyobb számban az élmény erős érzelmi hatásának adnak hangot, ezt követi az informális oktató jelleg, majd a szórakoztató jelleg említése (az elöbbi föleg történeti és szakmaspecifikus kiállításoknál, az utóbbi elsősorban magánmúzeumoknál). A látogatók meglepően ritkán nyilatkoznak mélyebben az általuk átélt múzeumi élményről a TripAdvisoron, viszont általánosak az elragadtatás (nem túl informatív) felsőfokú jelzői a mintában. Egy alapos látogatói élményvizsgálat túlmutat jelen kutatás keretein és értelemszerủen más módszertant igényel, azonban annyi megállapítható, hogy klasszikus képzőművészeti gyüjtemények nyújtják a leginkább passzív látogatói élményt (esztétikum). A látogatói tömeg, ami rontja a kiállítási élményt, egyedül Bécs kapcsán említtetik meg többször. Alig esik szó a látogatás motivációjáról és keretéről, főleg hobbi-látogatók és viszszatérő vendégek említik meg, esetleg a szervezett programon résztvevő turisták. Keveset tudunk meg arról is, honnan értesültek a látogatók a múzeumról, pedig ez a fiatal, magán és alapítványi fenntartású intézményeknél kulcsfontosságú: Az értékelők a TripAdvisor mellett legyakrabban útifilmet és úti- könyvet említenek forrásként. Az idegen nyelvü interpretáció nem jelent problémát az intézmények számára a látogatók szerint. Külön értékként jelenik meg mindhárom főváros esetében a helyi kultúrához kapcsolható örökség bemutatása. Az élmény után a legtöbb említés a múzeumok, mint attrakciók ajánlására vonatkozik, ami a látogatói elégedettség fontos indikátora.

\section{A KUTATÁS KORLÁTAI LIMITATIONS}

A kutatás korlátja, hogy nem reprezentatív mintavétellel mind a múzeumok, mind az értékelések esetében az alapsokaság töredékét vizsgálja. A kutatás további korlátja, hogy az angol nyelvü értékeléseken kívül más nyelvü véleményeket nem vesz figyelembe, így látogatói preferenciák esetleges kulturális különbségeit nem mutatja. Bár az elemzett vélemények kiválasztásakor szempont volt az időbeli szórás, az egy múzeumra jutó értékelések alacsony száma, valamint az esetenként igen hosszú véleményezési időszak nem tette lehetővé a vélhetően megjelenő trendek bemutatását.

\section{KÖVETKEZTETÉSEK ÉS JAVASLATOK CONCLUSIONS AND RECOMMENDATIONS}

A látogatói vélemények mennyisége szerinti sorrend nem tükrözi a három város turistaérkezési sorrendjét. Ahogy várható volt, Bécs történelmi és gyüjteménytörténeti okokból világhírủ múzeumai kapták messze a legtöbb értékelést és vonzzák feltehetően a legtöbb turistát ${ }^{1}$. A klasszikus múzeumok egyedül az osztrák fővárosban határozzák meg a TripAdvisor top 10-es listáját. Budapest és Prága esetében az intézmények több mint fele vagy viszonylag fiatal alapítású, magán, illetve alapítványi fenntartású, vagy pedig speciális területet bemutató, de hagyományos (állami/önkormányzati üzemeltetésủ) múzeum. Míg a hagyományos múzeumalapításnak és fenntartásnak nem - vagy nem elsődleges - célja a turisztikai hasznosítás, addig a magán üzemeltetésủ intézményeknél ez gyakran prioritás, ahogy az ezzel együtt járó, alapvetően látogató-orientált, szolgáltatói szemlélet is az. Ezt alátámasztja a TripAdvisor kiemelt látogatói

Küldőterület szerinti adatok nem állnak rendelkezésre, de jelentős külföldi látogatói arányra enged következtetni a bécsi Schönbrunni Kastély, a Kunsthistorisches Museum, a Belvedere és az Albertina egymillió fő feletti látogatója 2019-ben (www.wienkultur.info.at 2020) 
fórumként való kezelése is, ami alapvetően ezekre a múzeumokra jellemző (2. táblázat). A turista ma már a múzeumban is különleges élményt vár el, ahogy ezt az értékelések tartalomelemzésekor a legnagyobb számban említett fogalomtípus: az élmény minősítése is mutatja. Ezután a kiállitás és annak interpretációja kapta a legtöbb értékelést, ez utóbbin a belül összesítve a személyes interpretáció (tárlatvezetés) felülmúlta volumenben és elégedettségben is a modern technikai eszközöket. Ezt az eredményt torzíthatja egyrészt egy múzeum interpretrációs kínálata (befolyásoló tényező lehet, hogy a tárlatvezetés 6 vizsgált intézményben kötelezően a látogatás része, nem opció), másrészt a látogatói generáció (a $\mathrm{Z}$ és Alfa generáció tagjai várják el leginkább a digitális technikát), ugyanakkor kétségtelenül rámutat a humán tényező fontosságára a múzeumi szolgáltatásban. Ezt igazolja, hogy az alszempontrendszer elemei közül a legtöbb értékelés összesítve szintén a humán erőforrás kapcsán érkezett (a tárlatvezetés és a személyzet kapcsán).

Bécs múzeumi „erőforrásai” kétségtelen előnyt jelentenek, de ezekkel kapcsolatos a legtöbb kritika is, ami egyértelmúen a túlturizmusra és a nem megfelelö látogatómenedzsmentre utal. A mai múzeumlátogató már nem hódol az múlt öröksége előtt, ha kényelmetlennek ítéli meg a körülményeket. Ezzel szemben a szolgáltatás terén professzionális teljesítményt nyújtó, a minta szerint inkább Budapesten és Prágában jellemző termék-szemléletủ magán és alapítványi múzeumokat esetenként gyüjteményük kicsinysége vagy felszínesége miatt éri vád. Hoszszú távon csak minőségi (helyi) értékre építhető piacképes múzeumi szolgáltatás, ami - ahogy a TripAdvisor-on első helyezett, 2019-ben alapított cseh Nemzeti Filmmúzeum is mutatja - igen rövid idő alatt sikeresen tölthet be piaci réseket és kaphat nagy nyilvánosságot a látogatói értékelések által.

A kutatás eredményeire épülő javaslatok segíthetik a múzeumok pozícionálását a turisztikai piacon és hagyományos kultúraközvetítő szerepükben egyaránt. A föbb látogatói szegmensek, küldőpiacok igényeinek megismerése lehetővé teszi a testreszabott interpretáció és programlehetőségek létrehozását, a látogatómenedzsment fejlesztését, a leghatékonyabb marketingeszközök és csatornák kiválasztását. Ehhez javasolt a látogatókutatás stratégiai rendszerének kialakítása. Mivel a múzeum elsősorban demokratikus kultúraközvetítő intézmény, a látogatók megismerésének fontos hozadéka lehet a nemlátogatói rétegek feltárása és megszólításuk lehetősége. A múzeum, mint szolgáltató intézmény minőségbiztosítási rendszerének szükséges eleme a keresleti visszajelzés vizsgálata, aminek egyik hatékony eszköze az online - részben turisztikai - platformok követése. A múzeum virtuális közösségépitő funkcióját ösztönözheti a TripAdvisor-on folytatott kommunikáció a látogatókkal. A tudatos turisztikai szerepvállalás eredményeként a külföldi látogatók igényeit kielégítő szolgáltatások bevételei jelentős mértékủ pozitív hatással bírhatnak az intézményi gazdálkodásra.

\section{ÖSSZEGZÉS SUMMARY}

Bécs, Budapest és Prága kulturális turisztikai kínálata igen gazdag és egyben igen különbözö, ami múzeumaikban is megmutatkozik. Egy múzeum számos versenyelőnnyel bírhat, ám fontos látnunk, hogy ezek közül kevés az abszolút érvényủ tényezö: a látogatóbarát kialakítás és a személyes interpretáció elvárt és felértékelődő elem a klasszikus gyűjtemények kapcsán, az autenticitás és a minőségi kollekció pedig az új alapítású, piaci üzemeltetésủ intézmények esetében. Ezek figyelembevételével a múzeum turisztikai termékként is való menedzselése a minőségi turizmus alakításának fontos és hatékony eszköze lehet. 


\section{HIVATKOZÁSOK REFERENCES}

Budapesti Fesztivál és Turisztikai Központ (BFTK) (2019), Elemzés Budapest turisztikai piacáról, https://turizmus.com/szabalyozas-orszagmarketing/bftk-elemzes-budapest-turisztikai-piacarol-1162263 (Utolsó letöltés: 2020.01.28.)

Bodnár D. (2019), „Múzeumi látogatói élmény”, Turizmus Bulletin, 19(3), 38-51

Bodnár D., Jászberényi M., Ásványi K, (2017), „Az új muzeológia megjelenése a budapesti múzeumokban", Turizmus Bulletin, 17(1-2), $45-55$

Csapó J. (2020), A turizmuspolitika és a turizmusirányitás elmélete és gyakorlata az Európai Unióban, Budapest, Akadémiai

Czech Statistical Office (CZSO) (2020a), Collective accommodation establishments, $\mathrm{https}: / / \mathrm{vdb}$ czso.cz/vdbvo2/faces/en/index.jsf?page $=$ statistiky\&katalog=30838\#katalog=31742 (Utolsó letöltés: 2020.01.28.)

Czech Statistical Office (CZSO) (2020b), Population. https://www.czso.cz/csu/xa/casove_rady_ lide_time_series_people (Utolsó letöltés: 2020.01.28.)

Euromonitor International (2019), Top 100 City Destination, 2019 Edition, https://go.euromonitor.com/white-paper-travel-2019-100-cities. html (Utolsó letöltés: 2020.01.28.)

Falk, J. H. and Dierking, L. D. (2016), The Museum Experience Revisited 2/e, New York, Routledge

Gonda T., Csapó J. (2014), „Az Európa Kulturális Fővárosa cím elnyerésének hatása a kulturális turizmus és a kulturális ipar fejlődésére Maribor, Nagyszeben és Pécs esetében", Településföldrajzi Tanulmányok, 3(2), 154-165

International Council of Museums (ICOM) (2019), Museum definition, https://icom.museum/en/ activities/standards-guidelines/museum-definition/ (Utolsó letöltés: 2019.09.21.)

Központi Statisztikai Hivatal (KSH) (2019), Helyzetkép a turizmus, vendéglátás ágazatról 2018, http://www.ksh.hu/docs/hun/xftp/idoszaki/jeltur/jeltur18.pdf (Utolsó letöltés: 2019.06.07.)

Mantziou, L. (2019), „Museum Clusters as Urban Defibrillators", IOP Conference Series: Materials Science and Engineering, 471(6), 072046 DOI: 10.1088/1757-899X/471/7/072046

Magyar Szállodák és Éttermek Szövetsége (MSZÉSZ) (2019), Trend riport 2018 a hazai és nemzetközi szállodaipar teljesitményéröl, http:// turizmusonline.hu/hotel-szalloda/cikk/trend riport_2018_rol (Utolsó letöltés: 2020.01.27.)
Magyar Turisztikai Ügynökség (MTÜ) (2019a), A magyarországi kereskedelmi szálláshelyek 2018-as föbb eredményei, https://mtu.gov.hu/ documents/prod/Kereskedelmi_szallashelyek adatai_2018.pdf(Utolsó letöltés: 2020.01.27.)

Magyar Turisztikai Ügynökség (MTÜ) (2019b), A turizmus eredményei Magyarországon, https://mtu.gov.hu/cikkek/a-turizmus-eredmenyei-magyarorszagon (Utolsó letöltés: 2020.01.27.)

Magyar Turisztikai Ügynökség (MTÜ) (2019c), Budapest vendégforgalma 2018-ban, https:// $\mathrm{mtu} . \mathrm{gov} . \mathrm{hu} /$ documents/prod/Budapest_vendegforgalma_2018_3.pdf (Utolsó letöltés: 2020.01.27.)

Prague City Tourism (2019), 2018 Annual Report, https://www.praguecitytourism.cz/file/edee/en/ annual-reports/19006_vyrocni-zprava-2018_ en_a4_verze2_web.pdf (Utolsó letöltés: $20 \overline{2} 0.01 .27$.)

Statistik Austria (2020), Beherbergung, Ankünfte und Nächtigungen, http://www.statistik.at/ web_de/statistiken/wirtschaft/tourismus/beherbergung/ankuenfte_naechtigungen/index.html (Utolsó letöltés: 2020.02.11.)

TripAdvisor (2020), Bécs, Budapest és Prága legjobb 10 múzeuma, https://www.tripadvisor. com/Attractions-g190454-Activities-c49-Vienna.html, https://www.tripadvisor.co.hu/ Attractions-g274887-Activities-c49-Budapest_Central_Hungary.html, https://www. tripadvisor.com/Attractions-g274707-Activities-c49-Prague_Bohemia.html (Utolsó letöltés: 2020.01.27.)

Turizmus.com (2020), Hotelláz Budapesten: beérnek a fejlesztések, 20(1-2), 20-23

United Nations World Tourism Organization (UNWTO) (2019), International Tourism Highlights, 2019 Edition, https://www.e-unwto. org/doi/pdf/10.18111/9789284421152 (Utolsó letöltés: 2019.09.07.)

wien.gv.at (2020), Bevölkerung (Utolsó letöltés: 2020.01.30.)

wienkultur.info.at (2020): Kultur in Zahlen. (Utolsó letöltés:2020.01.30.)

Zátori A. (2014), „Városi turizmus és kultúra”, in: Jászberényi M. (szerk.): A kulturális turizmus sokszinüsége, Nemzeti Közszolgálati és Tankönyv Kiadó, Budapest, 93-113

1997. évi CXL törvény a muzeális intézményekröl, a nyilvános könyvtári ellátásról és a közmüvelödésröl,. $\quad$ https://net.jogtar.hu/jogszabaly?docid=99700140.tv (Utolsó letöltés: 2019.12.02.) 
Schultz Éva tanársegéd

Schultz.Eva@uni-bge.hu

Budapesti Gazdasági Egyetem

Kereskedelmi, Vendéglátóipari és Idegenforgalmi Kar

\section{Museum experience in 21st century. The competitiveness of Vienna, Budapest and Prague according to museum visitors' reviews}

\section{THE AIM OF THE PAPER}

The aim of this study is to enrich the comparative touristic analysis of Vienna, Budapest and Prague with a new aspect. Museums are important attractions and branding factors of city tourism. They play a significant role in quality tourism. Museums help sustainability through presenting local culture and lengthening season by their exhibitions, but they also have to face overtourism. A paradigm change is going on since the end of the $20^{\text {th }}$ century connected with the traditional cultural transmitting role of museal institutions During this process museums have been defined as scenes of informal lifelong learning, global wellbeeing or public space for generating dialogues and supporting equality in society.

\section{METHODOLOGY}

From touristic perspective the experience promise attracts tourist to museums, which is a complex phenomenon and an important interdisciplinary research topic nowadays. This paper examines the attractiveness of Budapest's and its regional competitors' museums and the visitors' expectations towards them based upon a content analysis of TripAdvisor reviews.

\section{MOST IMPORTANT RESULTS}

The best reviewed museums only in the case of Vienna are mostly classical cultural brands with international attractivity. To Budapest and Prague is more typical the presence of relatively young, service-oriented institutions based on special topics and operated by a company or foundation. Critical reviews focus on the insufficiencies of visitor management mainly connected to the classical type of museums, while on small size and/or poor quality of the exhibition related to the new one. The most mentioned concept type is the labelling of experience in which personal service and interaction play a significant role.

\section{RECOMMENDATIONS}

Findings can help positioning museums in the tourism market. The recognition of the main visitor segments' and source markets' demands needs further research which can support museums as service provider cultural institutions from several aspects (tailor-made interpretation, quality and visitor management, discovering and reaching new, potential markets).

Keywords: city tourism, museum, visitor experience 